\title{
Mindfulness and Shinrin-Yoku: Potential for Physiological and Psychological Interventions during Uncertain Times
}

\author{
Erica R. Timko Olson ${ }^{1} * *$, Margaret M. Hansen ${ }^{2}$ and Amber Vermeesch ${ }^{3}$ \\ 1 School of Nursing, University of Minnesota, Twin Cities Campus, 308 Harvard Street SE, \\ Minneapolis, MN 55455, USA \\ 2 School of Nursing and Health Professions, University of San Francisco, 2130 Fulton Street, \\ San Francisco, CA 94117, USA; mhansen@usfca.edu \\ 3 School of Nursing, University of Portland, 5000 N. Willamette Blvd, Portland, OR 97203, USA; \\ vermeesc@up.edu \\ * Correspondence: timko002@umn.edu
}

Received: 11 November 2020; Accepted: 10 December 2020; Published: 14 December 2020

\begin{abstract}
Mindfulness and Shinrin-yoku (SY) translated as forest bathing, is potentially effective to alleviate mental health issues related to the COVID-19 pandemic and beyond. The purpose of this article is to provide a translational and pragmatic approach to understanding mindfulness in the context of SY and psychological wellbeing through a rapid review of the literature. The background of mindfulness and SY practice are discussed and the emotional, neuroendocrine, and neurobiological responses are examined. Next, a rapid review of the literature examined six studies, published between 2010 and 2020 to determine what is known regarding the relationship between SY, mindfulness, and psychological wellbeing. The studies included 21-360 participants with a mean age of 20-55 years. The results demonstrated a significant positive correlation between nature, mindfulness, and measures of psychological wellbeing. During uncertain events, including COVID-19, weaving mindfulness with SY may be specifically important to at-risk groups, those experiencing depression, loneliness, and social isolation, and at-risk populations such as college students, veterans, and professionals with high levels of stress. The goal of this review is to provide a thorough background and support of this cost-effective modality to promote overall psychological wellbeing as a preventative measure to those at risk or experiencing psychological illnesses.
\end{abstract}

Keywords: mindfulness; Shinrin-yoku; forest bathing; anxiety; mental health; wellbeing

\section{Introduction}

The novel coronavirus (COVID-19) dashboard, presented by the Center for Systems Science and Engineering (CSSE) at Johns Hopkins University (JHU), illustrates the brevity of this unprecedented time of global uncertainty. As of 27 October 2020, there are 43,895,968 confirmed cases of COVID-19 in 189 countries with 1,165,455 deaths globally [1]. The confirmed individuals and others collectively have been seriously affected physically, psychologically, spiritually, and/or economically by this pandemic. From a psychological perspective, researchers quickly shined a light on the effects of COVID-19 epidemiological mandates, such as: fear of disease and death, fear of the threat to human existence, heightened state anxiety, social distancing, social isolation, and quarantine [2-5]. Mental health issues tend to be discounted in various cultures and societies even though mental illness accounts for one-third of adult disabilities worldwide [5]. Mental health interventions are to be actively available at all times and keenly recognized during and after unstable global catastrophes. Mindfulness practice has demonstrated significant positive effects on mental health concerns [6-13] while Shinrin-yoku (SY), 
translated as forest bathing has also demonstrated relaxing and healing effects. When evaluating these two modalities together, would there be a significant effect on emotional wellbeing? The authors' aims are to provide a background and rapid review of the literature pertaining to mindfulness and SY as interventions to alleviate mental health issues related to the COVID-19 pandemic and beyond.

\section{Background}

\subsection{Mindfulness}

Mindfulness has a long history, dating back to the Buddhist tradition in the first century BC. This history has countless understandings and several historical theories. Mindfulness has varied ways to practice with clinical, philosophical, religious, and secular approaches. With all the complexities within the practice of mindfulness, it is surprisingly not difficult to find common ground in writings and teachings. There are two main purposes of this ancient practice: coping and elimination of suffering, and positive changes in emotional states that lead to changes in behavior [6]. This has been simplified over the centuries to the understanding of "awareness of one's internal states and surroundings" [7] or "paying attention in a particular way; on purpose, in the present moment, and nonjudgmentally" [8]. When mindfulness is practiced and achieved, there is an improvement in mental, physical, emotional, and spiritual well-being [9].

Health care workers and college students are particularly vulnerable to the negative effects of the COVID-19 pandemic and mindfulness practices have demonstrated positive mitigation of these concerns [10]. Healthcare professionals who practice mindfulness have significant positive effects regarding stress, anxiety, burnout, depression, and psychological distress [11-13]. All of these stressors have a negative effect on the provision of patient care, which is of particular importance at this time, with stress, anxiety, and fear so prevalent in all aspects of patients' lives during this pandemic. College students, in particular, have high rates of stress and fatigue whereas mindfulness encourages engagement, focus, and learning [14].

Mindfulness research has been substantially increasing as an intervention to improve general health and well-being [15]. People are desiring to know and incorporate positive coping strategies [16]. Healthcare providers who participate in mindfulness programs, such as Mindfulness-Based Stress Reduction (MSBR) have experienced an increased quality of life and decreased perceived stress [17]. Research conducted in prison settings supports mindfulness interventions as having positive effects on the physical and mental health of inmates, instructors, and prison staff members [18].

Mindfulness provides many opportunities for a variety of practice methods. Several ways to practice include clinical/secular and philosophical/religious approaches. Some examples that have emerged are described here.

Clinical and secular approaches are used in a variety of settings. Mindfulness-Based Stress Reduction (MBSR) is a formal, 8-week program that is offered at medical centers across the United States. Instructors lead participants through mindfulness meditation techniques with stretches and postures from Hatha yoga. MBSR teaches how to positively handle daily stressors. Mindfulness-Based Cognitive Therapy (MBCT) is MBSR and cognitive therapy as a treatment for chronic depression. MBCT helps people to cope and manage personal thoughts and feelings. There is also Acceptance-Based Behavioral Therapy (ABBT) that includes MBSR and behavioral therapy to treat generalized anxiety disorder (GAD). GAD assists individuals to understand personal thoughts and emotions are normal, expected, and will increase and decrease from moment to moment.

Philosophical and religious approaches have been practiced for thousands of years. The root of mindfulness practice, as we understand it today, is derived directly from Buddhism. In order to practice mindful meditation, it is not required to have an understanding of Buddhism. It is an attempt to pay attention, to listen, and to be aware by simply noticing your breathing. It is gentle, appreciative, and nurturing [19]. An ancient practice in the Christian tradition is that of lectio divina. Lectio has roots in the Jewish synagogue, where Rabbis meditated on the Hebrew Scriptures [20]. In the 6th 
century, St. Benedict discussed the four phases: mind, heart, spirit, and body or read, meditate, pray, and contemplate [21]. We are called to rest in God's word and allow his vision and value to shape us [20]. Hinduism has deep roots in yoga and Vedic meditation that date back 2500-3500 years. Different types of Hindu mindful meditation today include Mantra Meditation, Transcendental Meditation, and Yoga Meditation. These are all ways to focus and silence the mind using a mantra or focus of attention, concentration, or visualization.

\subsubsection{Mindfulness Emotional Responses}

The effect of mindfulness on emotional response has been well documented in the literature ranging from fear conditioning, emotional learning, and reduction of post-traumatic stress disorder symptoms [22]. Roemer, Williston, and Rollins [23] found mindfulness to be associated with enhanced emotional recovery, reduced negative emotional responses, reduction in behavioral avoidance and decreases in emotional regulation difficulties. Roomer and colleagues [23] continue with the interpretation of their findings to indicate the practice of mindfulness is associated with healthy emotion regulation.

Long and Christian [24], explored the effect of mindfulness as a buffer to ruminative thoughts and negative emotional responses including injustice and retaliation. Their findings are supportive of the buffering effects of mindfulness on ruminative and negative emotional responses which lessen retaliation. This bolster to self-regulation is especially important to health care workers who, through secondary trauma, are likely to experience higher levels of stress leading to negative emotional responses. Long and Christian [24] were among the first researchers to focus on mindful self-regulation in a workplace setting. As the workplace culture shifts to focus on healthier environments, this type of research is imperative to the creation of sustainable and functional workplace environments that support active measures to decrease deleterious circumstances, including retaliation and automaticity. Measures such as this have the potential to increase job satisfaction, retention, and performance through decreasing negative emotional responses.

The central pillar of Gestalt therapy is awareness which is directly related to the practice of mindfulness [25]. Through increasing mindfulness, the practice of MBSR impacts the modification of emotional responses including those associated with fear response and conditioning [22]. Highlights of this research suggested underlying neural plasticity related to mindfulness practice and its impact on the sensitivity of emotional responses [22]. Practitioners of mindfulness are encouraged to turn toward unpleasant emotions and stimuli rather than away [26]. This is similar to research on increasing the performance and endurance threshold of elite athletes [27]. This research is significant because of the negativity correlated with trait anxiety levels thus suggesting understanding the neural plasticity associated with mindfulness training can be incorporated into successful and sustainably anti-anxiety interventions. Björkstrand et al. [28] found mindfulness training had a positive effect on emotional function through the retention of safety learning protocols for healthy individuals. This has profound implications for the potential treatment of anxiety and trauma-related psychological disorders such as posttraumatic stress disorders [29,30].

Relating the effect of mindfulness on fear-based behaviors is highlighted by the research conducted by Orellana-Rios et al. [31] and the importance of developing a mindful presence, cultivating loving-kindness, and inner-self acceptance into daily work activities. Relating the effects of mindfulness on fear-based behaviors is important for the increase in the skills for the self-care strategies toolbox and minimizing the fear of unpleasant circumstances. Incorporating these skills in daily work activities, makes these skills more accessible and sustainable for a larger population. Targeting practitioners and their patients with mindfulness and compassion-oriented practices will be beneficial for all involved.

\subsubsection{Neuroendocrine Responses}

Regarding mindfulness and neuroendocrine effects, the literature [32] suggests mindfulness practice is associated with down-regulation of nuclear factor kappa $B$, the opposite of chronic stress 
effects, and thus associated with a reduced risk of inflammation-related disease. This connection is important when considering chronic disease management and prevention, as well as chronic work stressors on employees [33].

Even brief (3-day) mindfulness meditation training has been shown to reduce self-reported perceived stress [34]. However, the increase of salivary cortisol in the same experiment suggests a greater coping effort and cortisol reactivity during evaluative stressors [34]. These results suggest, and are in line with previous research, mindfulness skill acquisition may be mentally demanding but further research is needed to determine the extent of this response.

\subsubsection{Neurobiological Responses}

The neurobiological correlates of mindfulness meditation are especially interesting on impulsivity and emotional regulation [35-37]. Guendelman et al. [37] explored mindfulness-based regulation interventions to more clearly explore and define a top-down and bottom-up perspective. Mindfulness emotional regulation strategies tend to use a bottom-up approach where the individual regulates emotional response through mindful awareness versus a cognitive reappraisal which relies on a top-bottom mechanism. Guendelman et al. [37] concluded mindfulness practices change the bottom-up emotional regulation system including emotional generation and implicit emotional regulation through long-term meditation training. Although these strategies focus on different aspects including interoceptive-proprioception, sensory-perception, and cognitions and thought process of emotional regulation, the end goal benefits of emotional regulation are clearly accessible to both casual and the expert meditator [37].

\subsection{Shinrin-Yoku (Forest Bathing)}

Shinrin-yoku (SY) is a Japanese word first identified by the Director of the Japanese Forestry Agency, Tomohide Akiyama, in 1982 as a method to attract people to visit the Japanese forests. The Japanese characters, or Kanji, for Shinrin-yoku are 森林浴. The first character represents a forest (three trees), the second character symbolizes a wood and the third character corresponds with bathe (flowing water on the left of the character and a valley on the right side of the character). When translated into English, it means forest bathing and is similar to the English nuance of sunbathing. The practice of slowly and mindfully walking in the forest environment while using all five senses led Japanese scientists to research the physiological and psychological outcomes of experiencing nature [38].

Initially, Miyazaki [38] conducted physiological experiments in 1990 on Japanese participants living in Yakushima because of the plethora of hinoki cedar trees. The effects of SY on the levels of the stress hormone, cortisol, were initially measured because an increase in the number of people living in cities and urban areas were identified as experiencing higher levels of stress. In a decade, new techniques evolved to measure the SY effects on the autonomic nervous system (e.g., brain wave activity) and the incidence of research increased in the 2000s to provide credence to the preventative prescription for enhancing wellbeing and placing less strain on the healthcare system.

Current published research, centered on the physiological health benefits, has increased over the past decade [39-42]. The physiological health benefits include decreased blood pressure, decreased levels of oxyhemoglobin in the prefrontal cortex, decreased pulse rate, decreased cortisol levels, and decreased heart rate variability (HRV). Most recently, perhaps due to the COVID-19 pandemic, there is a multitude of references pertaining to SY and nature therapy (NT) research by various researchers deeply looking at the relaxing and healing effects of receiving stimuli from natural environments, such as plants, flowers, trees, forests, various woods, and running water in natural environments.

\subsubsection{SY Emotional Responses}

Focusing on the natural world through an emotional lens of awe may have a positive effect on human health and well-being. Flora and fauna also may create safe and secure places for individuals to reflect on emotions, investigate feelings while minimizing the stress response, and provide an 
opportunity to journal emotions that arise while being exposed to nature and green spaces. According to Bethelmy and Corraliza [43], nature is a commonly acknowledged source of transcendent emotion and research has shown nature's brawn to bring about strong human emotions. The aforementioned researchers generated abstract and operative definitions of a human's sublime emotion toward nature. Based on recent research regarding the feeling of awe, Bethelmy and Corraliza [43] developed an instrument to measure sublime emotion toward nature and recruited 280 participants from the general population of Madrid, Spain to determine the conceptual definition of sublime emotion. Results indicated two conceptual determinants: awe and inspiring energy. Writers and researchers have identified positive affective effects radiating from the concept of awe, as a specific emotional state. Precisely, the awe experienced in nature settings reduced human stress-related symptoms and increased overall human wellbeing [44,45].

Exposure to nature, such as green spaces, may have a shielding effect on a human's mental well-being, such as reported favorable effects on the human stress response. Hunter and colleagues [46] demonstrated 10-30 min of quiet stillness in nature lowers the stress hormone, cortisol. Bratman and associates [47] determined individuals who walked $90 \mathrm{~min}$ in nature compared with individuals who walked 90 min along a busy urban road ruminate less about themselves and had a reduction in the activity of the subgenual prefrontal cortex (sgPFC). The sgPFC part of the human brain is an area showing sadness, human withdrawal, and reflection on negative emotional experiences via magnetic resonance imagery (MRI). Furthermore, viewing photographs or videos of nature scenes have a restorative effect, such as fewer negative feelings and increased reported positive moods. Whereas viewing images of urban scenes do not have a soothing effect reported by research participants [48].

\subsubsection{SY Neuroendocrine Responses}

The neuroendocrine effects of SY are clearly presented in a recent systematic review conducted by Wen and colleagues [49]. Li and co-researchers [50] investigated the effects of SY on cardiovascular health and metabolic factors of 19 middle-aged Japanese male participants. Following a $2.6 \mathrm{~km}$ walk (80 min each in the morning and afternoon) in an urban treeless environment and controlling for the exact exposure in a forest environment on two consecutive Saturdays in Japan, the participants' blood and urine samples were collected before and after each trip. In addition, participants' blood pressure and pulse rates were measured during the trips, as well as the Japanese version of the Profile of Mood States (POMS) was conducted before, during, and after each walk. The forest bathing environment walks significantly reduced participants' pulse rate and significantly increased the stamina score and significantly decreased the scores for anxiety, confusion, depression, and fatigue. Showing a tendency toward a decline in urinary adrenaline and a significant drop in urinary dopamine was indicated among the forest bathing program when compared to the urban walking program. Additionally, serum adiponectin, an adipocyte secreted protein that decreases inflammation in the cardiovascular system, was elevated amongst the forest bathing walkers.

Ochiai and research colleagues [51] recruited middle-aged males with high-normal blood pressure in an attempt to study the effects of time spent walking and relaxing in a forest environment on blood pressure and other physiological and psychological factors associated with human stress. The physiological and psychological parameters were measured the same time of day before and circa two hours following the forest walk in order to control for circadian effects. The systolic and diastolic blood pressure readings, as well as urinary adrenaline and serum cortisol, were significantly lower $(p<0.05)$ than baseline following the forest walk. Therefore, these results indicate a forest therapy intervention that has a positive effect on individuals who have been diagnosed with cardiovascular disease.

As mentioned before, SY has been documented as a stress-reducing integrative medicine modality. Kobayashi and colleagues [52] conducted a randomized crossover study and reported the effect of viewing a forest environment versus viewing an urban landscape on male participants $(n=348)$ 
salivary cortisol concentrations. Each participant sat on a chair for $15 \mathrm{~min}$ while viewing a forest environment and then $15 \mathrm{~min}$ viewing an urban environment for $15 \mathrm{~min}$. The intervention sites were 34 forest sites and 34 urban sites (city centers) scattered across Japan. The participants' saliva was collected immediately following each 15-min intervention. Frequency distributions of salivary cortisol intensities, as reported as mode, were in a range from 5.73 to $6.55 \mathrm{nmol} / \mathrm{L}$ for both groups. However, the participants with a higher salivary cortisol level $(>10 \mathrm{nmol} / \mathrm{L})$ were larger in the urban group $(n=84)$ than in the forest environment $(n=44)$. Furthermore, cortisol levels were significantly lower in the forest environment group (mean: $6.88 \mathrm{nmol} / \mathrm{L}$, median: $6.35 \mathrm{nmol} / \mathrm{L}$ ) than in an urban environment group (mean: $7.98 \mathrm{nmol} / \mathrm{L}$, median: $7.45 \mathrm{nmol} / \mathrm{L}$ ), and the variation test revealed these differences were statistically significant $(p<0.001)$.

These three studies provide a snapshot of the current research conducted on the SY effects on the neuroendocrine human system. According to the physiological anthropologist and deemed father of forest bathing, Miyazaki [53], designed the back-to-nature-theory purporting since humans evolved in nature it is where humans feel most comfortable and achieve homeostasis. Miyazaki and associates [54-57] have extensively conducted and published studies involving physiological markers, such as the autonomic nervous system (heart rate variability), central nervous system (EEG, fMRI and PET scans), endocrine systems (cortisol, adrenaline, nor-adrenaline, immunoglobulin A, and the immune system (natural killer cells).

\subsubsection{Neurobiological Responses}

Song and research associates [55] examined the effect of viewing real forest landscapes on human prefrontal brain activity. Song et al. [55] set out to conduct this research because there is limited evidence-based research involving brain activity changes when exposed to forest environments. Twenty-nine females (age: $21 \pm 1.4$ years) were recruited across five forest and five urban environments and were asked to view forest and urban scenes for 15 min each. The oxyhemoglobin (Oxy-hb) levels were constantly measured in the right and left pre-frontal areas of the brain while the participants viewed each scene and the results indicated a lower level of Oxy-hb in the participants' right pre-frontal lobes while viewing forest landscapes. This area of the human brain is associated with physiological relaxation and these results showed less oxygen uptake in this region of the brain is necessary while viewing nature landscapes. This recently published study supports prior studies [56,57] and studies conducted in a nature therapy laboratory $[58,59]$.

This provided review of the recent research conducted in the areas of neuroendocrine and neurobiological effects associated with SY supports and improves mental health wellbeing. Shinrin-yoku is a living medicine that has been with us for over seven million years as humans evolved in nature $(99.9 \%)$ versus the time we have spent in urban cities $(0.01 \%)$ (personal communication, Miyazaki, 2018). Applying Miyazaki's Concept of Nature Therapy [53] to today's human stressed state during this unprecedented pandemic and global warming times is warranted. The Concept of Nature Therapy is a top-down concept that starts with a stressed state and from this mindful stressed state one looks for exposure to flowers, wood products, and forests with a result in physiological relaxation and immune function recovery, hence resulting as preventive medicine. Weaving mindfulness with this Concept of Nature Therapy may be applied to mental health risk groups, such as depression, loneliness, and social isolation during uncertain events as recently experienced at the global level.

\section{Materials and Methods}

A rapid review was conducted to determine what is known regarding the relationship between SY, mindfulness, and measures of psychological wellbeing at this critical time of a global pandemic with COVID-19 (Table 1). A literature search was conducted using the keywords: nature, mindfulness, Shinrin-yoku, psychological wellbeing, and mental health. Inclusion criteria included: peer-reviewed article, published between 2010 and 2020, English language, and mindfulness in nature to measure psychological wellbeing outcomes. Exclusion criteria included: systematic reviews. A total of 29 articles were reviewed with a total of six meeting the inclusion and exclusion criteria. 
Table 1. Review of Literature.

\begin{tabular}{|c|c|c|c|c|c|c|}
\hline Author/Date & $\begin{array}{c}\text { Research } \\
\text { Question(s)/Hypotheses }\end{array}$ & Methodology & Assessment Tools & Analysis \& Results & Conclusions & $\begin{array}{l}\text { Implications for Future } \\
\text { Research }\end{array}$ \\
\hline $\begin{array}{l}\text { Huynh \& Torquati } \\
\text { (2019) }\end{array}$ & $\begin{array}{l}\text { The authors proposed a } \\
\text { model to describe how } \\
\text { stress, connection to } \\
\text { nature and mindfulness } \\
\text { work together to } \\
\text { improve } \\
\text { psychological wellbeing. }\end{array}$ & $\begin{array}{l}\text { Survey, } 273 \text { in } 2016 \\
\text { and } 2019,2016-237 \\
\text { females, } 36 \text { males, } \\
\text { 2019—87 males. } \\
\text { Undergraduate student }\end{array}$ & $\begin{array}{c}\text { Connection to Nature } \\
\text { Scale, Mindful Attention } \\
\text { Awareness Scale, } \\
\text { Philadelphia } \\
\text { Mindfulness Sale, } \\
\text { Perceived Stress Scale, } \\
\text { Satisfaction with Life } \\
\text { ts Scale, Hospital Anxiety } \\
\text { and Depression Scale, } \\
\text { Positive States of } \\
\text { Mind Scale }\end{array}$ & $\begin{array}{l}\text { Descriptive statistics and bivariate } \\
\text { correlations were conducted } \\
\text { CN was positively correlated with } \\
\text { mindful attention, mindful } \\
\text { awareness, positive states of mind } \\
\text { and life satisfaction. CN was } \\
\text { inversely correlated with perceived } \\
\text { stress, anxiety and depression. } \\
\text { Mindful attention and acceptance } \\
\text { were positively associated with } \\
\text { positive states of mind and life } \\
\text { satisfaction. Mindful awareness } \\
\text { was inversely associated with } \\
\text { perceived stress and depression } \\
\text { and positively corelate with } \\
\text { positive states of mind and } \\
\text { life satisfaction }\end{array}$ & $\begin{array}{c}\text { Mindfulness } \\
\text { significantly mediated } \\
\text { the association between } \\
\text { connection to nature and } \\
\text { psychological well-being } \\
\text { and significantly } \\
\text { moderated the } \\
\text { association between } \\
\text { perceived stress and two } \\
\text { indicators of } \\
\text { psychological well-being. }\end{array}$ & $\begin{array}{l}\text { Replication in an } \\
\text { experimental design to } \\
\text { determine causation } \\
\text { would be warranted }\end{array}$ \\
\hline $\begin{array}{l}\text { Lücke, Braumandl, } \\
\text { Becker, Moeller, } \\
\text { Custal, Philipsen } \\
\text { \& Müller (2019) }\end{array}$ & $\begin{array}{c}\text { Evaluate the efficacy of } \\
\text { nature-based } \\
\text { mindfulness training in } \\
\text { professional with high } \\
\text { levels of } \\
\text { work-related stress. }\end{array}$ & $\begin{array}{l}\text { Intervention, Pilot, } \\
56 \text { convenience } \\
\text { sample, } 8 \text { in control } \\
\text { group, assessment at } \\
\text { baseline, } 2 \text { months } \\
\text { and } 4 \text { months } \\
\text { into training }\end{array}$ & $\begin{array}{c}\text { Self-Efficacy (SWE), } \\
\text { Sense of Coherence Scale } \\
\text { (SOC-L9), Freiburg } \\
\text { Mindfulness Inventory } \\
\text { (FMI), Symptom } \\
\text { Checklist 90 (SCL-90) }\end{array}$ & $\begin{array}{l}\text { Pre-post comparisons, paired } \\
\text { t-tests, compared between } \\
\text { treatment and control using } \\
\text { unpaired t-tests } \\
\text { Baseline and } 2 \text { months: Significant } \\
\text { positive effects in SWE, SOC and } \\
\text { FMI and SCL with further subtle } \\
\text { improvements through the } \\
\text { remaining study time } \\
\text { Control group showed a worsening } \\
\text { of SOC between T1 and T2. }\end{array}$ & $\begin{array}{c}\text { Participants benefited } \\
\text { from the training in level } \\
\text { of mindfulness, } \\
\text { self-efficacy and sense of } \\
\text { coherence. The } \\
\text { improvements were } \\
\text { small, but the } \\
\text { psychiatric burden } \\
\text { decreased by } 40 \% \text { where } \\
\text { there may be benefits to } \\
\text { this intervention that } \\
\text { were not measured. }\end{array}$ & $\begin{array}{l}\text { Larger sample size with } \\
\text { increased power, } \\
\text { experimental design } \\
\text { with randomization }\end{array}$ \\
\hline $\begin{array}{c}\text { Marchand, } \\
\text { Klinger, Block, } \\
\text { VerMerris, } \\
\text { Herrmann, } \\
\text { Johnson, Paradiso, } \\
\text { Scott \& Yabko } \\
\text { (2019) }\end{array}$ & $\begin{array}{l}\text { MT/NE might provide a } \\
\text { synergistic healing } \\
\text { benefit from both the } \\
\text { development of } \\
\text { mindfulness skills and } \\
\text { the benefits of } \\
\text { nature exposure. }\end{array}$ & $\begin{array}{c}\text { Intervention, pilot, } \\
21 \text { veterans, } 13 \text { male, } \\
8 \text { females, mean age } \\
55 \text {, all had at least } \\
\text { one psychiatric } \\
\text { disorder with } 75 \% \\
\text { having } 2 \text { or more. } \\
5 \text { sessions } 1 x / \text { week } \\
\text { over } 5 \text { weeks, } \\
\text { classroom } \\
\text { instruction, } \\
\text { mindfulness } \\
\text { and sailing, }\end{array}$ & $\begin{array}{c}\text { State train anxiety } \\
\text { inventory (STAI), } \\
\text { Acceptance and Action } \\
\text { Questionnaire II } \\
\text { (AAQ-II), Five Facet } \\
\text { Mindfulness } \\
\text { Questionnaire (FFMQ) }\end{array}$ & $\begin{array}{l}\text { Paired 2-tailed t-tests for pre and } \\
\text { post intervention comparison } \\
\text { No significant findings in } \\
\text { psychological flexibility (AAQ-II) } \\
\text { Significant decrease in scores on } \\
\text { the STAI and significant increase in } \\
\text { scores on the FFMQ } \\
\text { 92\% enjoyed the experience, } 100 \% \\
\text { stated they felt calm and relaxed, } \\
33 \% \text { requested more time sailing }\end{array}$ & $\begin{array}{c}\text { Pilot study: determined } \\
\text { to be an acceptable and } \\
\text { feasible intervention for } \\
\text { this population, even } \\
\text { those with } \\
\text { physical limitations. } \\
\text { May positively impact } \\
\text { treatment engagement } \\
\text { and reduce the burden } \\
\text { of illness }\end{array}$ & $\begin{array}{c}\text { Expand the study to } \\
\text { both veteran and wider } \\
\text { community participants } \\
\text { Larger sample } \\
\text { with randomization }\end{array}$ \\
\hline
\end{tabular}


Table 1. Cont

\begin{tabular}{|c|c|c|c|c|c|c|}
\hline Author/Date & $\begin{array}{c}\text { Research } \\
\text { Question(s)/Hypotheses }\end{array}$ & Methodology & Assessment Tools & Analysis \& Results & Conclusions & $\begin{array}{l}\text { Implications for Future } \\
\text { Research }\end{array}$ \\
\hline $\begin{array}{c}\text { Sadowdki, Böke, } \\
\text { Mettler, Heath \& } \\
\text { Khoury (2020) }\end{array}$ & $\begin{array}{l}\text {-Assess the relationships } \\
\text { between nature } \\
\text { relatedness, the five } \\
\text { facets of dispositional } \\
\text { mindfulness and } \\
\text { dimension of } \\
\text { subjective wellbeing. } \\
\text {-Evaluate the influence } \\
\text { of the five facets of } \\
\text { dispositional } \\
\text { mindfulness as possible } \\
\text { mediators between } \\
\text { nature relatedness and } \\
\text { the dimension of } \\
\text { subjective wellbeing }\end{array}$ & $\begin{array}{c}\text { Survey, } 250 \\
\text { University students } \\
\text { Mean age: } 20.67\end{array}$ & $\begin{array}{l}\text { The Five Facets of } \\
\text { Mindfulness Questionnaire, } \\
\text { The Nature Relatedness } \\
\text { Scale, The Positive and } \\
\text { Negative Affect } \\
\text { Schedule, } \\
\text { The Satisfaction with } \\
\text { Life Scale }\end{array}$ & $\begin{array}{c}\text { SPSS, Pearson's biserial } \\
\text { correlations, separate } \\
\text { mediation analysis } \\
\text { Significant positive associate } \\
\text { between nature relatedness and } \\
\text { positive affect, life satisfaction, } \\
\text { non-reactivity } \\
\text { Five facets of dispositional } \\
\text { mindfulness were related with } \\
\text { overall subjective wellbeing }\end{array}$ & $\begin{array}{c}\text { For female university } \\
\text { students, connecting } \\
\text { with nature may be more } \\
\text { likely to be associated } \\
\text { with increased in } \\
\text { positive psychological } \\
\text { outcomes rather than } \\
\text { decreases in } \\
\text { negative symptoms. } \\
\text { Nature relatedness and } \\
\text { elements of wellbeing } \\
\text { may be explained by the } \\
\text { nonreactivity and } \\
\text { observing qualities of } \\
\text { mindfulness }\end{array}$ & $\begin{array}{c}\text { Cost effective, accessible } \\
\text { modality for } \\
\text { implementation in } \\
\text { college health centers } \\
\text { health services, } \\
\text { Further research with } \\
\text { larger randomized } \\
\text { samples for greater } \\
\text { generalizability } \\
\text { and power }\end{array}$ \\
\hline $\begin{array}{c}\text { Wolsko \& } \\
\text { Lindberg (2013) }\end{array}$ & $\begin{array}{l}\text { Examining the } \\
\text { relationship between } \\
\text { psychological well-being } \\
\text { and the personal } \\
\text { experience of connection } \\
\text { with nature. }\end{array}$ & $\begin{array}{c}\text { Survey, } 256 \\
\text { participants, } 2 \text { year } \\
\text { community college, } \\
\text { mean age } 30.11\end{array}$ & $\begin{array}{l}\text { Connection to Nature } \\
\text { (CNS), Mindful } \\
\text { Attention Awareness } \\
\text { Scale, Flourishing Scale, } \\
\text { Scale of Positive and } \\
\text { Negative Experience, } \\
\text { Subjective Vitality Scale }\end{array}$ & $\begin{array}{c}\text { Correlation and confirmatory } \\
\text { factor analysis } \\
\text { Higher scores on CNS showed } \\
\text { significance with higher levels of } \\
\text { trait mindfulness, flourishing, } \\
\text { vitality, positive emotion and lower } \\
\text { levels of negative emotions } \\
\text { Higher levels of trait mindfulness } \\
\text { showed significant relationships } \\
\text { with flourishing, vitality, positive } \\
\text { emotion and lower levels of } \\
\text { negative emotions }\end{array}$ & $\begin{array}{c}\text { Significant relationship } \\
\text { across all measures } \\
\text { including CNS and all } \\
\text { measure of } \\
\text { psychological wellbeing } \\
\text { and mindfulness }\end{array}$ & $\begin{array}{l}\text { Further studies across a } \\
\text { variety of samples to } \\
\text { determine generalizability }\end{array}$ \\
\hline $\begin{array}{l}\text { Yeong Choe, } \\
\text { Jorgensen \& } \\
\text { Sheffield (2020) }\end{array}$ & $\begin{array}{l}\text { AIM: Investigate } \\
\text { whether the impacts of a } \\
\text { commonly used } \\
\text { wellbeing intervention } \\
\text { (MSBR) are enhanced } \\
\text { when combined with the } \\
\text { natural environment } \\
\text { Hypothesis 1: MBSR } \\
\text { achieves the best mental } \\
\text { health and wellbeing } \\
\text { outcomes when } \\
\text { conducted in a } \\
\text { natural environment }\end{array}$ & $\begin{array}{l}\text { Intervention, } 99 \\
\text { students and staff } \\
\text { from a volunteer } \\
\text { email list at a } \\
\text { university. } \\
\text { Mean age } 36.35 \\
\text { Divided into } 3 \\
\text { groups: natural } \\
\text { outdoor, built } \\
\text { indoor and indoor } \\
\text { environment. Each } \\
\text { participated in a } 6 \\
\text { week MBSR } \\
\text { program of } 1 \mathrm{~h}\end{array}$ & $\begin{array}{c}\text { Five Facet Mindfulness } \\
\text { Questionnaire, Nature } \\
\text { Relatedness Scale, } \\
\text { Positive and Negative } \\
\text { Affect Schedule, } \\
\text { Rumination-Reflection } \\
\text { Questionnaire, } \\
\text { Depression Anxiety } \\
\text { Stress Scales }\end{array}$ & $\begin{array}{c}\text { Natural Environment showed } \\
\text { greatest adherence, SPSS, ANOVA, } \\
\text { MANOVA } \\
\text { Positive Affect: Significant Effect } \\
\text { over time } \\
\text { Negative Affect: Significant impact } \\
\text { in natural outdoor environment } \\
\text { Rumination: significant } \\
\text { interactions between time and } \\
\text { environment significant decrease } \\
\text { persisted in the outdoor } \\
\text { environment } \\
\text { Depression: significant for time } \\
\text { Anxiety: significant for time } \\
\text { Stress: Significant for time } \\
\text { and environment }\end{array}$ & $\begin{array}{l}\text { All three groups showed } \\
\text { significant changes to } \\
\text { mental health and } \\
\text { wellbeing. Only the } \\
\text { natural outdoor } \\
\text { environment group had } \\
\text { improved nature } \\
\text { connectedness, } \\
\text { rumination, reflective } \\
\text { attitudes, and stress } \\
\text { reduction over the } \\
\text { intervention including a } \\
\text { one-month follow-up }\end{array}$ & $\begin{array}{l}\text { Continue to study the } \\
\text { beneficial effects of } \\
\text { nature and mindfulness } \\
\text { and an intervention to } \\
\text { support well-being, } \\
\text { resilience and improve } \\
\text { mental health. }\end{array}$ \\
\hline
\end{tabular}




\section{Results}

\subsection{Sample and Study Characteristics}

The number of subjects in the studies ranged from 21 to 360 with a mean age range between 20.67 and 55 years. The studies not reporting mean age ranges were conducted in a university setting [60], or a work setting [61]. All the research studies measured mindfulness and emotional health outcomes. Two of the studies did not include a connection or relationship with nature questionnaire [61,62] though the studies took place in an outdoor setting. The studies included both survey $[60,63,64]$ and interventional $[61,62,65]$ studies. All studies used convenience sampling and one study did have a small control group [61]. The search also included two pilot studies [61,62].

The purpose of three of the studies was to determine the relationship between nature, mindfulness, and psychological wellbeing outcomes $[60,63,64]$. The remaining study purposes were to examine the effects of mindfulness training within an outdoor nature environment $[61,62,65]$.

\subsection{Results}

The results showed overall, that there is a significant positive correlation between nature, mindfulness, and measures of psychological wellbeing. Two studies discussed the positive benefits of mindfulness training in nature with the reduction of the burden of illness related to the intervention [61,62] by as much as $40 \%$ [61]. Specific psychological conditions such as anxiety, depression, and psychological stress showed significant benefits from mindfulness in nature [60,65]. Connection or relatedness to nature scores was correlated to an increase in mindfulness $[60,63,64]$ and measures psychological wellbeing [60,63-65]. Mindfulness was positively correlated with measures of psychological wellbeing [60-63,65].

\subsection{Limitations}

Research in this area is limited due to small sample sizes, lack of adequate power, at higher than desired attrition rates. The authors of all the studies reported the need for larger sample sizes with randomization to increase power and a greater variety of participants to provide generalizability.

\subsection{Conclusion}

Mindfulness and SY interventions are a cost-effective modality that can be implemented in a variety of settings to promote overall psychological wellbeing to at-risk populations such as college students, veterans, and professionals with high levels of work-related stress.

\section{Discussion}

\section{Mindfulness and Shinrin-Yoku Connection}

Two are better than one because they have good return for their work: If one falls down, his friend can help him up. But pity the man who falls and has no one to help him up. Also, if two lie down together, they will keep warm. But how can one keep warm alone? Though one may be overpowered, two can defend themselves. A cord of three strands is not quickly broken. (Ecclesiastes 4:9-12)

Human beings have the innate capacity for health and wellbeing [66]. This capacity is reaching for balance and respite in an ever-changing environment. Yet, nature is also reaching for balance and respite in every changing relationship with humankind. Both humans and nature are seeking, searching, striving to develop the symbiotic relationship that has existed for millennia. Ancient writings reveal spiritual practices of contemplation during challenging times that people would retreat to nature, the deep forest, and the most desolate desert, for days, weeks, months, and even years seeking wellbeing. 
We are seeing some increased threats to psychological and emotional wellbeing while nature is showing she may be damaged beyond repair, both in need of healing. Supporting mindfulness in nature will result in a symbiotic relationship that is beneficial to both human wellbeing and nature, rather than destructive of both [67]. Symbiosis is from the Greek word sumbios, companion, to sumioun, live together, and finally symbiosis, a living together [68].

Additionally, mindfulness and SY support environmental well-being. When mindfulness is practiced within SY there is an increase in connection with nature and a reestablishment and strengthening of this bond [69]. With the decline of nature in urban areas, it is even more important to expand the understanding of the benefits to promote a pro-environmental attitude and behavior to strengthen psychological wellbeing.

SY helps to support interconnectedness to nature but it is significantly greater when participants engaged in mindfulness [60,63,64,69]. Mindfulness supports a deeper connection with nature and may support achieving those benefits more efficiently [70]. The health effects of outdoor activities were greatly enhanced when engagement strategies of mindfulness were incorporated into nature activities [62]. Psychological well-being was more likely when people were engaged and interacted with the environment through mindfulness [60,63-65,71]. In addition, time in nature can enhance mindfulness while fostering physical, psychological, and spiritual well-being while supporting the development of insight into the reality of the present situation [67].

\section{Conclusions}

In this year of 2020, we have seen over 40 million cases and greater than 1.1 million deaths from COVID-19 [1]. This has caused significant physical, psychological, spiritual, and economic distress to people and the environment, all around the globe. Accessible mental health interventions need to be available and utilized to alleviate further destruction. Mindfulness practice has been shown to improve mental, physical, emotional, and spiritual wellbeing [9]. Techniques can be clinically based, such as MBSR and MBCT [62,65], or philosophically/religiously based from Buddhism, Judaism, Christianity, and Hinduism [19-21]. SY experiences have demonstrated a decrease in the stress response [38] and multiple overall health benefits [39-42]. Mindfulness and SY have shown an increase in positive emotional responses [31,43-48], neuroendocrine effects [24-32,49-57], and even neurobiological responses [35-37,55-59]. The greatest effects may be best utilized together with the support of the symbiotic relationship of humanity and nature [60-65]. Additional information is available in the supplementary materials. Mindfulness and SY support the health and healing of both self and nature. Psychological wellbeing is greatly enhanced and supported when humanity can slow down, be present, be mindful, rest in the woods, and allow the healing power of nature to perform her healing work from within.

Supplementary Materials: The following are available online at http://www.mdpi.com/1660-4601/17/24/9340/s1.

Author Contributions: Writing original draft preparation, E.R.T.O.; M.M.H.; A.V.; review and editing, E.R.T.O.; M.M.H.; A.V.; supervision, E.R.T.O.; All authors have read and agreed to the published version of the manuscript.

Funding: This research received no external funding.

Conflicts of Interest: The authors declare no conflict of interest.

\section{References}

1. Johns Hopkins University; Medicine Coronavirus Resource Center. Available online: https://coronavirus.jhu. edu/map.html (accessed on 12 June 2020).

2. Cao, W.; Fang, Z. The psychological impact of the COVID-19 epidemic on college students in China. Psychiatry Res. 2020, 287, 112934. [CrossRef] [PubMed]

3. Talevi, D.; Socci, V. Mental health outcomes of the CoViD-19 pandemic. Rivista Psichiatria 2020, 55, 137-144.

4. Lai, J.; Ma, S. Factors associated with mental health outcomes among health care workers exposed to coronavirus disease 2019. JAMA Netw. Open 2020, 3, e203976. [CrossRef] [PubMed] 
5. Otu, A.; Charles, C.H. Mental health and psychosocial well-being during the COVID-19 pandemic: The invisible elephant in the room. Int. J. Ment. Health Syst. 2020, 14, 38. [CrossRef] [PubMed]

6. Purser, R.E.; Milillo, J. Mindfulness revisited: A Buddhist-based conceptualization. J. Manag. Inq. 2014, 24, 3-24. [CrossRef]

7. APA Dictionary of Psychology. Available online: https://dictionary.apa.org/mindfulness (accessed on 26 October 2020).

8. What Is Mindfulness: Definition + Benefits. Available online: https://positivepsychology.com/what-ismindfulness/ (accessed on 4 November 2020).

9. Davis, D.M.; Hayes, J.A. What are the benefits of mindfulness? A practice review of psychotherapy-related research. Psychotherapy 2011, 48, 198-208. [CrossRef]

10. Balasubramanian, A.; Paleri, V.; Bennett, R.; Paleri, V. Impact of COVID-19 on the mental health of surgeons and coping strategies. Head Neck 2020, 42, 1638-1644. [CrossRef]

11. Spinelli, C.; Wisener, M.; Khoury, B. Mindfulness training for healthcare professionals and trainees: A meta-analysis of randomized controlled trials. J. Psychosom Res. 2019, 120, 29-38. [CrossRef]

12. La Torre, G.; Raffone, A.; Peruzzo, M.; Calabrese, L.; Cocchiara, R.A.; D’Egidio, V.; Leggieri, P.F.; Dorelli, B.; Zaffina, S.; Mannocci, A. Yomin collaborative group. Yoga and mindfulness as a tool for influencing affectivity, anxiety, mental health, and stress among healthcare workers: Results of a single-arm clinical trial. J. Clin. Med. 2020, 9, 1037. [CrossRef]

13. De Cieri, H.; Shea, T.; Cooper, B.; Oldenburg, B. Effects of work-related stressors and mindfulness on mental and physical health among Australian nurses and healthcare workers. J. Nurs Scholarsh. 2019, 51, 580-589. [CrossRef]

14. Chase-Cantarini, S.; Christiaens, G. Introducing mindfulness moments in the classroom. J. Prof. Nurs. 2019, 35, 389-392. [CrossRef] [PubMed]

15. Krageloh, C.U.; Henning, M.A.; Medvedev, O.N.; Feng, X.J.; Moir, F.; Bellington, R.; Siegert, R.J. Mindfulness-Based Intervention Research: Characteristics, Approaches and Developments; Routledge: New York, NY, USA, 2019.

16. Champion, L.; Economides, M.; Chandler, C. The efficacy of brief app-based mindfulness intervention on psychosocial outcomes in healthy adults: A pilot randomised controlled trial. PLoS ONE 2018, 13, e0209482. [CrossRef] [PubMed]

17. Benzo, R.P.; Anderson, P.M.; Bronars, C.; Clark, M. Mindfulness for healthcare providers: The role of non-reactivity in reducing stress. Explore 2018, 14, 453-456. [CrossRef] [PubMed]

18. Bouw, N.; Huijbregts, S.C.J.; Scholte, E.; Swaab, H. Mindfulness-based stress reduction in prison: Experiences of inmates, instructors, and prison staff. Int. J. Offender Ther. Comp. Criminol. 2019, 63, 2550-2571. [CrossRef] [PubMed]

19. Kabat-Zinn, J. Wherever You Go There You Are; Hyperion: New York, NY, USA, 1994.

20. Paintner, C.V.; Wynkoop, L. Lectio Divina: Contemplative Awakening and Awareness; Paulist Press: Mahwah, NJ, USA, 2008.

21. Fry, T.; Baker, I. RB 1980: The Rule of St. Benedict in Latin and English with Notes; Liturgical Press: Collegeville, PA, USA, 1981.

22. Hölzel, B.K.; Brunsch, V.; Gard, T.; Greve, D.N.; Koch, K.; Sorg, C.; Lazar, S.W.; Milad, M.R. Mindfulness-based stress reduction, fear conditioning, and the uncinate fasciculus: A pilot study. Front. Behav. Neurosci. 2016, 10, 124. [CrossRef] [PubMed]

23. Roemer, L.; Williston, S.K.; Rollins, L.G. Mindfulness and emotion regulation. Curr. Opin. Psychol. 2015, 3, 52-57. [CrossRef]

24. Long, E.C.; Christian, M.S. Mindfulness buffers retaliatory responses to injustice: A regulatory approach. J. Appl. Psychol. 2015, 100, 1409. [CrossRef]

25. Joyce, P.; Sills, C. Skills in Gestalt Counselling \& Psychotherapy; Sage Publisher: Newbury Park, CA, USA, 2018.

26. Santorelli, S. Heal Thy Self: Lessons on Mindfulness in Medicine; Three Rivers Press: New York, NY, USA, 2000.

27. Thienot, E.; Adams, D. Mindfulness in Endurance Performance. Endurance Performance in Sport: Psychological Theory and Interventions; Routledge: London, UK, 2019.

28. Björkstrand, J.; Schiller, D.; Li, J.; Davidson, P.; Rosen, J.; Martensson, J.; Kirk, U. The effect of mindfulness training on extinction retention. Sci. Rep. 2019, 9, 19896. [CrossRef] 
29. Kummar, A.S. Mindfulness and fear extinction: A brief review of its current neuropsychological literature and possible implications for posttraumatic stress disorder. Psychol. Rep. 2018, 121, 792-814. [CrossRef]

30. Bremner, J.D.; Mishra, S.; Campanella, C.; Shah, M.; Kasher, N.; Evans, S.; Fani, N.; Shah, A.J.; Reiff, C.; Davis, L.L.; et al. A pilot study of the effects of mindfulness-based stress reduction on post-traumatic stress disorder symptoms and brain response to traumatic reminders of combat in operation enduring freedom/operation iraqi freedom combat veterans with post-traumatic stress disorder. Front. Psychiatry 2017, $8,157$.

31. Orellana-Rios, C.L.; Radbruch, L.; Kern, M.; Regel, Y.U.; Anton, A.; Sinclair, S.; Schmidt, S. Mindfulness and compassion-oriented practices at work reduce distress and enhance self-care of palliative care teams: A mixed-method evaluation of an "on the job "program. BMC Palliat. Care 2018, 17, 3. [CrossRef] [PubMed]

32. Pradhan, B.; Gogineni, R.; Sharma, S. Mind, mindfulness, and the social brain: Psychobiological understandings and implications. Indian J. Soc. Psychiatry 2018, 34, 313-322.

33. Ilies, R.; Aw, S.S.; Lim, V.K. A naturalistic multilevel framework for studying transient and chronic effects of psychosocial work stressors on employee health and well- being. Appl. Psychol. 2016, 65, 223-258. [CrossRef]

34. Creswell, J.D.; Pacilio, L.E.; Lindsay, E.K.; Brown, K.W. Brief mindfulness meditation training alters psychological and neuroendocrine responses to social evaluative stress. Psychoneuroendocrinology 2014, 44, 1-12. [CrossRef]

35. Lutz, J.; Brühl, A.B.; Doerig, N.; Scheerer, H.; Achermann, R.; Weibel, A.; Jäncke, L.; Herwig, U. Altered processing of self-related emotional stimuli in mindfulness meditators. NeuroImage 2016, 124, 958-967. [CrossRef]

36. Korponay, C.; Dentico, D.; Kral, T.R.A.; Kruis, A.; Davis, K.; Goldman, R.; Lutz, A.; Davidson, R. The effect of mindfulness meditation on impulsivity and its neurobiological correlates in healthy adults. Sci. Rep. 2019, 9, 11963. [CrossRef]

37. Guendelman, S.; Medeiros, S.; Rampes, H. Mindfulness and EMOTION REGULATION: Insights from neurobiological, psychological, and clinical studies. Front. Psychol. 2017, 8, 220. [CrossRef]

38. Miyazaki, Y. Shinrin-Yoku: The Japanese Way of Forest Bathing for Health and Relaxation; Aster: London, UK, 2018.

39. Ka-Yin Yau, K.; Loke, A.Y. Effects of forest bathing on pre-hypertensive and hypertensive adults: A review of the literature. Environ. Health Prev. Med. 2020, 25, 1-17.

40. Hansen, M.; Jones, R.; Tocchini, K. Shinrin-Yoku (forest bathing) and nature therapy: A state-of-the-art review. Int. J. Environ. Res. Public Health 2017, 14, 851. [CrossRef]

41. Ikei, H.; Miyazaki, Y. Positive physiological effects of touching sugi (Cryptomeria japonica) with the sole of the feet. J. Wood Sci. 2020, 66, 29. [CrossRef]

42. Rajo, S.R.; Daljit, S.K.; Abdullah, M.Z. The physiological and psychosocial effects of forest therapy: A systematic review. Urban For. Urban Green. 2020, 54, 126744. [CrossRef]

43. Bethelmy, L.C.; Corraliza, J.A. Transcendence and sublime experience in nature: Awe and inspiring energy. Front. Psychol. 2019, 10, 509. [CrossRef] [PubMed]

44. Passmore, H.A.; Howell, A.J. Eco-existential positive psychology: Experiences in nature, existential anxieties, and well-being. Humanist. Psychol. 2014, 42, 370-388. [CrossRef]

45. Mayo Clinic Health Letter. The Power of Awe. Available online: https://healthletter.mayoclinic.com/issues/ september-2020/the-power-of-awe (accessed on 22 September 2020).

46. Hunter, M.R.; Gillespie, B.W.; Chen, S.Y.-P. Urban nature experiences reduce stress in the context of daily life based on salivary biomarkers. Front. Psychol. 2019, 10, 22. [CrossRef]

47. Bratman, G.N.; Hamilton, J.P.; Hahn, K.S.; Daily, G.C.; Gross, J.J. Nature experience reduces rumination and subgenual prefrontal cortex activation. Proc. Natl. Acad. Sci. USA 2015, 112, 8567-8572. [CrossRef]

48. Golding, S.E.; Gatersleben, B.; Cropley, M. An experimental exploration of the effects of exposure to images of nature on rumination. Int. J. Environ. Res. Public Health 2018, 15, 2. [CrossRef]

49. Wen, Y.; Yan, Q.; Pan, Y.; Gu, X.; Liu, Y. Medical empirical research on forest bathing (Shinrin-yoku): A systematic review. Environ. Health Prev. Med. 2019, 24, 70. [CrossRef]

50. Li, Q.; Kobayashi, M.; Kumed, S.; Ochiai, T.; Miura, T.; Kagawa, T.; Imai, M.; Wang, Z.; Otsuka, T.; Kawada, T. Effects of forest bathing on cardiovascular and metabolic parameters in middle-aged males. Evid. Based Compl. Alt. 2016, 2587381,1-7. [CrossRef]

51. Ochiai, H.; Ikei, H.; Song, C.; Kobayashi, M.; Takamatsu, A.; Miura, T.; Kagawa, T.; Li, Q.; Kumenda, S.; Imai, M.; et al. Physiological and psychological effects of forest therapy on middle-aged males with high-normal blood pressure. Int. J. Environ. Res. Public Health 2015, 12, 2532-2542. [CrossRef] 
52. Kobayashi, H.; Song, C.; Ikei, H.; Park, B.J.; Lee, J.; Kagawa, T.; Miyazaki, Y. Population-based study on the effect of a forest environment on salivary cortisol concentration. Int. J. Environ. Res. Public Health 2017, 14, 931. [CrossRef]

53. Miyazaki, Y. Nature Therapy. [PowerPoint slides]; Chiba University: Chiba, Japan, 2018.

54. Kobayashi, H.; Park, B.; Miyazaki, Y. Normative references of heart rate variability and salivary alpha-amylase in a healthy young male population. J. Physiol. Anthropol. 2012, 31, 9. [CrossRef] [PubMed]

55. Song, C.; Ikei, H.; Kagawa, T.; Miyazaki, Y. Effect of viewing real forest landscapes on brain activity. Sustainability 2020, 12, 6601. [CrossRef]

56. Park, B.J.; Tsunetsugu, Y.; Kasetani, T.; Hirano, H.; Kagawa, T.; Sato, M.; Miyazaki, Y. Physiological effects of Shinrin-yoku (taking in the atmosphere of the forest)-Using salivary cortisol and cerebral activity as indicators. J. Physiol. Anthropol. 2007, 26, 123-128. [CrossRef] [PubMed]

57. Li, Q.; Morimoto, K.; Kobayashi, M.; Inagaki, H.; Katsumata, M.; Hirata, Y.; Hirata, K.; Suzuki, H.; Li, Y.J.; Wakayama, Y.; et al. Visiting a forest, but not a city, increases human natural killer activity and expression of anti-cancer proteins. Int. J. Immunopathol. Pharmacol. 2008, 21, 117-127. [CrossRef]

58. Ikei, H.; Song, C.; Miyazaki, Y. Physiological effect of olfactory stimulation by Hinoki cypress (Chamaecyparisobtusa) leaf oil. J. Physiol. Anthr. 2015, 34, 44. [CrossRef]

59. Jo, H.; Song, C.; Ikei, H.; Enomoto, S.; Kobayashi, H.; Miyazaki, Y. Physiological and psychological effects of forest and urban sounds using high-resolution sound sources. Int. J. Environ. Res. Public Health 2019, 16, 2649. [CrossRef]

60. Huynh, T.; Torquati, J.C. Examining connection to nature and mindfulness at promoting psychological well-being. J. Environ. Psychol. 2019, 66, 101370. [CrossRef]

61. Lücke, C.; Braumandl, S.; Becker, B.; Moeller, S.; Custal, C.; Philipsen, A.; Müller, H.H.O. Effects of nature-based mindfulness training on resilience/symptom load in professional with high work-related stress-levels: Findings from the WIN-Study. Ment. Illn. 2019, 11, 20-24. [CrossRef]

62. Marchand, W.R.; Klinger, W.; Block, K.; VerMerris, S.; Herrmann, T.S.; Johnson, C.; Paradiso, N.; Scott, M.; Yabko, B. Mindfulness training plus nature exposure for veterans with psychiatric and substance use disorders: A model intervention. Int. J. Environ. Res. Public Health 2019, 16, 4726. [CrossRef]

63. Sadowdki, I.; Böke, N.; Mettler, J.; Heath, N.; Khoury, B. Naturally mindful? The role of mindfulness facets in the relationship between nature relatedness and subjective well-being. Curr. Psychol. 2020. [CrossRef]

64. Wolsko, C.; Lindberg, K. Experiencing Connection With Nature: The Matrix of Psychological Well-Being, Mindfulness, and Outdoor Recreation. Ecopsychology 2013, 5, 80-91. [CrossRef]

65. Yeong Choe, E.; Jorgensen, A.; Sheffield, D. Does a natural environment enhance the effectiveness of Mindfulness-Based Stress Reduction (MBSR)? Examining the mental health and wellbeing, and nature connectedness benefits. Landsc. Urban Plan. 2020, 202, 103886. [CrossRef]

66. Kreitzer, M.J.; Koithan, M. Integrative Nursing, 2nd ed.; Oxford University Press: New York, NY, USA, 2019.

67. Van Gordon, W.; Shonin, E.; Richardson, M. Mindfulness and Nature. Mindfulness 2018, 9, 1655-1658. [CrossRef]

68. Oxford Languages. Available online: https://languages.oup.com/google-dictionary-en/ (accessed on 24 October 2020).

69. Unsworth, S.; Palicki, S.K.; Lustig, J. The impact of mindful meditation in nature on self-nature interconnectedness. Mindfulness 2016, 7, 1052-1060. [CrossRef]

70. Nisbet, E.K.; Zelenski, J.M.; Grandpierre, Z. Mindfulness in nature enhances connectedness and mood. Ecopsychology 2019, 11, 81-91. [CrossRef]

71. Duvall, J. Enhancing the benefits of outdoor walking with cognitive engagement strategies. J. Environ. Psychol. 2011, 31, 27-35. [CrossRef]

Publisher's Note: MDPI stays neutral with regard to jurisdictional claims in published maps and institutional affiliations. 